\title{
Stability of contracts in the Brazilian wine industry ${ }^{1}$
}

Decio Zylbersztajn* Marcelo Miele**

\begin{abstract}
A variety of contracts between wineries and grape growers are observed in Brazil. This study addresses the concept of coordination of food chains, particularly the stability of contractual relationships. A qualitative analysis of industry-farmers contracts is presented, followed by a quantitative analysis testing transaction cost economics-based hypothesis. Scale, location, age of vineyard, and the cooperative organizational form are addressed in terms of the effect on the stability of contracts. Vertical and horizontal coordination are addressed.

Data come from a sample of 139 grape-growers that supplied 10 major wineries. The results show that more stable contracts or vertical integration are characteristic of high quality wine production, where the need
\end{abstract}

\footnotetext{
*Faculdade de Economia, Administração e Contabilidade da Universidade de São Paulo, Pesquisador CNPq, Centro de Conhecimento em Agronegócios - PENSA. E-mail: dezylber@usp.br

**EMBRAPA - Concórdia, SC. E-mail: miele@cnpsa.embrapa.br

${ }^{1}$ Authors would like to thank Elizabeth Farina, Fabio R. Chaddad, James T. Wright, and two anonymous referees, for the suggestions and reviews of earlier versions. We also thank Dra. Loiva Maria de Mello Freire for providing access to the EMBRAPA`s database, at the Center for Research in Wines, Bento Gonçalves and Marislei Nishima for the statistical support. Paper presented at the conference of the International Food and Agribusiness Management Association - The Netherlands, at the Congress of the International Society for the New Institutional Economics /Berkeley and at the Congress of the Brazilian Society for Agricultural Economics. The remaining errors and omissions are the exclusive responsibility of the authors.
} 
for strict contractual coordination is more relevant, i.e. risk of hold up losses is larger. We test the hypothesis that site specificity and qualityrelated specific investments are associated with more stable contractual architectures. Farmers' cooperatives present poorer performance but tend to hold more stable relationships with their members, possibly the result of adverse selection, since specialized farmers prefer to maintain contracts with investor-owned wineries, instead of farmers' cooperatives. Conclusions are presented in the final part.

Key words: Contract Stability, Contract Coordination, Re-contracting.

\section{JEL Classification: D23, Q13}

\section{Introduction}

Coordination of contractual relationships in the presence of specific assets has been addressed in the literature on vertical integration and longterm contracts as presented in Klein (1978), Williamson (1985), Joskow (1985) and Zylbersztajn and Lazarinni (2005). The literature on contracts has an unexplored dimension represented by the stability measures of the contractual relationship. Different from contract duration, stability explores the frequency with which parties re-contract when alternatives are available. The study of the determinants of stability of contracts in the Brazilian wine industry is the key contribution of the paper.

Stability is still more relevant when the focus is the food chain. Food safety and specific quality attributes are more relevant today than in the past due to two factors. First, liability related to consumer rights imposes the design of new tools to coordinate entire food chains. Second, complex contracts linking specialized agents in the production and distribution chain are more common. In order to assure quality standards firms have incentives to cooperate, sharing assets and developing specific tacit knowledge.

The observation of strategies in the food industry points to the growing importance of quality-related aspects and, therefore, the need to structure stable contractual relationships among different and specialized agents, in the production and distribution chains. Agro-food systems are 
characterized by high level of asset specific investments. Changing quality standards, food safety concerns, time specifications, specific legislation protecting consumer rights, and environmental awareness are examples of why it is difficult to rely on autonomous adaptations.

What makes the food industry particularly interesting to study is the fact that quality attributes are seldom one-dimensional, most of the time being the result of collaborative strategies involving several agents throughout the production and distribution chain. The design of a strictly coordinated contractual device (Zylbersztajn and Farina, 1999) is necessary in order to reach the desired quality standards, whether in terms of food safety or other aspects demanded by consumers.

The wine industry is an example of why strict coordination is necessary in order to transform the regional technical potential to produce high quality wines in real performance. The successful example of Californian, Australian, and Chilean wines indicates that new organizational architectures are as important as specific regional characteristics in producing quality attributes. Both traditional countries as well as the new players have made significant investments in the high quality systems of wine production (Geene et al., 1999).

The Brazilian wine industry is being challenged by several factors. First, the limited production of classic varietals causes a problem of stability in the supply of good quality grapes to the industry. Between 1990 and 1997 about one thousand farmers are reported to have left the activity (Miele, 2001). Second, persistent problems of horizontal coordination and controls are observed, due to opportunistic behavior, exemplified, but not limited to, by the addition of products to the wine. Cheating is possible since monitoring costs are high, no central authority is "de facto" responsible for the control, leading to a typical problem of lemons, where good and bad quality products dispute the market place $^{2}$. Third, the climate in Rio Grande do Sul is borderline to allow for regularity of desirable quality attributes, with implications for farmers who make specific investments in classical varieties under risky conditions, so we expect a premium for coordination efforts. Fourth, the new legislation for denomination of origin does not provide incentives for

\footnotetext{
${ }^{2}$ The "lemon problem" was proposed by Akerlof,1970.
} 
farmers to make quality-related specific investments. Fifth is the level of interest rates, precluding the intentions of farmers to reform their vineyards. Sixth is the absence of a system to monitor quality with power to exclude underscored production, and seventh is the cost of production due to the small scale of production.

This paper is structured in five parts. Following this introduction the institutional arrangement is described, focused on the Brazilian emerging system of top-level varietal wines. The study explores the contrasts between the governance architecture adopted by low and top quality wine production. Special attention is given to the differences in the contractual architecture adopted by different agents engaged in the production of top quality wines, particularly the farmers' cooperatives, whose importance appears to have declined in recent years.

Part Three discusses the chain coordination, based on recent literature, deriving the regularities in contracts between farmers and industries. Part Four presents the empirical analysis, first defining a proxy for contractual stability and then testing transaction cost-based explanatory variables, which are different measures to assess specific investments. A conclusive discussion is presented in Part Five. Extensions of the approach for addressing specific aspects of quality in the food industry are suggested.

\section{Organization of the Brazilian Industry}

Winery was introduced in Brazil by Portuguese and Italian colonization that settled in the State of Rio Grande do Sul. It has been followed by the first independent association of producers, which deepened the role of coordination in terms of standards and technological innovation. The Brazilian structure of production in the South is more like the European, based on small family based vineyards, in contrast with the larger scale seen in USA or Australia.

The development of the industry shaped the organization found in the beginning of the 2000 's, in which $90 \%$ of the production was made on 13 thousand small farms. The production of grapes is directed to the market of juice or to the production of wines, while production for fresh consumption is organized in the warmer regions, especially in the Northeast area under irrigation. Small vineyards can be found, with an 
average scale of 1.9 hectares with a production of 385 million tons of grapes in $1999,14 \%$ of which are classical vine varieties.

In 2000 the wineries were organized as 276 processing industries, 22 farmers' cooperatives, and 133 small winegrowers, exploring small scale, family-made wines, some with well-recognized local brands. Vertically integrated winegrowers explored a diversified set of activities, including restaurants and rural tourism.

Based on official data, 8 among the 22 farmers' cooperatives and 63 among the 276 industries produced wines from classic varieties, showing a reduction in the participation of cooperatives and an increase in investment-owned firms.

Total wine production in 1999 was 311 million liters, of which 15\% was from classical vinifera varieties. Especial varieties counted for $10 \%$ of the total production of grapes in 2002 and $11.7 \%$ in 2003 . The industry shows heterogeneous technological level, declining number of cooperatives, increasing exports of low value-added grape juice, and an increase in domestic demand for fine wines.

We define as top quality the fine wines originated from classic varieties, under strict control of the winery, and presenting attributes recognized by the market. Since we have a mixture of easy and difficult to measure characteristics, we assume that farmers that produce classical varieties are the ones that supply the necessary (but not sufficient) elements to produce top level wines. It is possible that good quality farmers also offer low quality grapes to the industry, since the wineries also sell a range of different quality attributes at different prices. However, for the purpose of this study, it is sufficient to know that farmers with low quality do not make specific investments and are related to the low quality winery. The top quality group make specific investments and also build more complex contractual mechanisms to provide incentives and monitoring activities.

This situation leads to the question of how to develop incentives to improve the production of classic wines based in long lasting relations between growers and industries. If, on one hand, technology adoption is important, this paper suggests that coordination tools must be considered relevant in order to transform potential into real market participation, especially due to the risky technological conditions related to quality standards. This specific aspect will be addressed in the following chapter. 


\section{Institutional Arrangement of the Brazilian Wine Industry}

The co-existence of sub-systems in the Brazilian wine industry is shaping the private strategies focused on quality. Specialty wines demand strictly coordinated systems of transactions in order to fulfill the quality needs of the wineries, which are tied to distributors through long-term contracts. Some specific features of the industry are germane to this study.

Asset Specific Investments: Specific investments are necessary in order to structure contract arrangements capable of coordinating the high quality production chain. Specific equipment is needed by the processing industry, followed by specific investments in brand development, which in the Brazilian case is not supported by a well developed legislation of denomination of origin. Vineyards should make investments in classic varieties, and also in human capital upgrading its capacity to carry best agronomic practices and management.

For the farmers, the specific investment has a lower value at the alternative allocation, which is production of unbranded bulk wine or selling to the growing grape juice industry. For the industry, investments in equipment and brand development, especially related to the establishment of long-term relationships with the supermarket channel, are necessary in order to guarantee specific signals from final consumers, transmitted through the retail chains.

Site and time specificity are relevant, since contracts are coordinated with a large number of small farmers and the product is highly perishable, leaving a narrow flexibility window between harvesting and processing.

Risk: Local climatic conditions of rain and other natural characteristics can make difficult to maintain stable quantity and quality of vintages. This introduces a risk element that must be considered in the design of the contractual relationships between farmers and industry.

Land Ownership Structure: Land tenure is based on small family-owned and managed vineyards. This aspect, added to the hilly geographical characteristics, precludes the exploration of scale, which shapes farmers-industry contractual architecture.

Transaction cost economics suggests the need for strictly coordinated contracts, in order to protect the value of specific investments. 
The theory suggests that vertical integration or long-term contracts are aligned with the characteristics of transactions, which is in accordance with the observed institutional arrangements. A number of small and medium size winegrowers are forward integrated into distribution, with their own brands offering small-scale production for tourists and local supermarkets. Farmers also show forward integration through cooperatives, improving the ability to coordinate the production both horizontally and vertically. Long-term contracts are difficult to set, due to the high instability in production, being replaced by annual recursive contracts.

Table 1: Governance structure of wineries in Rio Grande do Sul (Sample, year 2000).

\begin{tabular}{|c|c|r|r|r|r|r|}
\hline & Form & $\begin{array}{c}\text { Area } \\
\text { (ha) }\end{array}$ & $\begin{array}{c}\text { Production } \\
\text { (kg) I }\end{array}$ & $\begin{array}{r}\text { Procurement } \\
(\mathbf{k g}) \S\end{array}$ & $\begin{array}{c}\text { VI(\%) } \\
\#\end{array}$ & \multicolumn{1}{c|}{$\begin{array}{c}\text { Scale } \\
\text { II }\end{array}$} \\
\hline Winery D & Cooperative & - & - & $1,976,994$ & $0.0 \%$ & $3.4 \%$ \\
\hline Winery E & Cooperative & - & - & $1,221,140$ & $0.0 \%$ & $2.1 \%$ \\
\hline Winery C & Cooperative + VI & 17.00 & 238,000 & $7,735,700$ & $3.1 \%$ & $13.2 \%$ \\
\hline Winery A & $\mathrm{M}+\mathrm{VI}$ & 12.00 & 168,000 & $3,046,277$ & $5.5 \%$ & $5.2 \%$ \\
\hline Winery H & $\mathrm{M}+\mathrm{VI}$ & 33.00 & 462,000 & $6,225,507$ & $7.4 \%$ & $10.6 \%$ \\
\hline Winery B & $\mathrm{VI}+$ contracts & 30.00 & 420,000 & $1,778,342$ & $23.6 \%$ & $3.0 \%$ \\
\hline Winery F & $\mathrm{VI}+$ contracts & 1.5 & 21,000 & 64,368 & $32.6 \%$ & $0.1 \%$ \\
\hline Winery J & $\mathrm{VI}+\mathrm{M}$ contracts & 50.00 & 700,000 & $1,345,136$ & $52.0 \%$ & $2.3 \%$ \\
\hline Winery I & $\mathrm{VI}+\mathrm{M}$ & 10.00 & 140,000 & 187,573 & $74.6 \%$ & $0.3 \%$ \\
\hline Winery G & VI $+\mathrm{M}$ & 40.00 & 560,000 & 605,048 & $92.6 \%$ & $1.0 \%$ \\
\hline Total sample & & 193.50 & $2,709,000$ & $24,186,085$ & $11.2 \%$ & $41.2 \%$ \\
\hline
\end{tabular}

I more than $14000 \mathrm{~kg} / \mathrm{ha}$

$\S$ varietals in 2000

\# only varietals

II consider all processing (capacity specialties and commodities)

Source: Secretaria da Agricultura do Rio Grande do Sul

Table 1 describes the institutional arrangement found in the 10 wineries studied. The total production represents $41.2 \%$ of the procurement of quality wine-grapes in 1999. Three different institutional arrangements can be seen, namely, cooperatives, vertically integrated companies, and market transactions, the supply being complemented by annual contracts between growers and wineries. Cooperatives showed poorer performance and the data suggest a declining participation in the industry. Degrees of backward integration in grape production were found, ranging from zero to $92.6 \%$. Market transactions complemented the supply needs of the wineries. 
Cooperatives were important forms for architecting vertical and horizontal relationships. If, on the one hand, important improvements in horizontal and vertical coordination can be provided by marketing cooperatives, other costs tend to emerge, mostly related to governance and capital allocation (Cook, 1994).

\subsection{Incentives and Monitoring}

In order to provide incentives for quality enhancement different contractual incentives have been introduced. Payment for quality attributes is one based on the sugar content, the maturity stage of grapes, the sanitary conditions, and the acidity of the product. Other aspects are important, such as the historic information of farmers ' characteristics with details on the mode of transportation, cultivation technology, and storage conditions. The information was collected by the industries, introducing important reputation elements in the contract.

Most of the wineries provide technical assistance to farmers, as a way to maintain long-term informal contracts with key suppliers. This incentive provides relevant information about the adoption of good practices by farmers. Table 2 provides the goals of each of the 10 wineries studied, and the incentive mechanisms built in to the contracts with suppliers, in terms of price differentials, controls, monitoring, technical assistance, and supply of clone seedlings. 
Table 2: Observed contractual coordination incentives.

\begin{tabular}{|c|c|c|c|c|c|}
\hline Winery & Goals & Incentives & Contracts & $\begin{array}{c}\text { Technical } \\
\text { Support }\end{array}$ & Loans \\
\hline $\mathrm{D}$ & $\begin{array}{l}\text { - Quality } \\
\text { improvement } \\
\text { - Varietals } \\
\end{array}$ & Market prices & $\begin{array}{l}\text { - individual files } \\
\text { - joint planning } \\
\text { of production } \\
\end{array}$ & 0.62 & 278 \\
\hline $\mathrm{E}$ & $\begin{array}{l}\text { - Quality } \\
\text { - Diversification }\end{array}$ & $\begin{array}{l}\text { Quality } \\
\text { Premium }\end{array}$ & $\begin{array}{l}\text { - individual files } \\
\text { - joint planning } \\
\text { of production } \\
\end{array}$ & 0.38 & 57 \\
\hline $\mathrm{C}$ & $\begin{array}{l}\text { - Quality } \\
\text { - Specific varietals }\end{array}$ & $\begin{array}{l}\text { Quality } \\
\text { Premium }\end{array}$ & $\begin{array}{l}\text { - individual files } \\
\text { - joint planning } \\
\text { of production }\end{array}$ & 0.72 & 72 \\
\hline A & $\begin{array}{l}\text { - Quality } \\
\text { - Self-sufficiency }\end{array}$ & Market prices & $\begin{array}{l}\text { - individual files } \\
\text { - joint planning } \\
\text { of production }\end{array}$ & 0.57 & 154 \\
\hline $\mathrm{H}$ & $\begin{array}{l}\text { - Quality } \\
\text { - Specific varietals }\end{array}$ & $\begin{array}{l}\text { Quality } \\
\text { Premium } \\
\text { Reputation }\end{array}$ & $\begin{array}{l}\text { - individual files } \\
\text { - joint planning } \\
\text { of production } \\
\text { - classification } \\
\text { by quality } \\
\text { levels } \\
\end{array}$ & 0.27 & 100 \\
\hline B & $\begin{array}{l}\text { - } \text { specific varietals } \\
\text { - self-sufficiency }\end{array}$ & $\begin{array}{l}\text { Quality } \\
\text { Premium }\end{array}$ & $\begin{array}{l}\text { - individual files } \\
\text { - joint planning } \\
\text { of production }\end{array}$ & 1.20 & 479 \\
\hline $\mathrm{F}$ & $\begin{array}{l}\text { - Quality } \\
\text { - Self-sufficiency }\end{array}$ & Market prices & $\begin{array}{l}\text { - files } \\
\text { - follows } \\
\text { individual } \\
\text { performance }\end{array}$ & 14.29 & - none \\
\hline $\mathrm{J}$ & $\begin{array}{l}\text { - Quality } \\
\text { - Self-sufficiency }\end{array}$ & $\begin{array}{l}\text { Quality } \\
\text { Premium }\end{array}$ & $\begin{array}{l}\text { - files } \\
\text { - monitor } \\
\text { technology } \\
\end{array}$ & 5.00 & 3,200 \\
\hline I & $\begin{array}{l}\text { - Quality } \\
\text { - Self-sufficiency }\end{array}$ & $\begin{array}{l}\text { Quality } \\
\text { Premium }\end{array}$ & - None & - None & - none \\
\hline G & $\begin{array}{l}\text { - Quality } \\
\text { - Self-sufficiency }\end{array}$ & Market prices & - None & - None & - none \\
\hline
\end{tabular}

Source: authors

Even with the incentives provided by the wineries, the production of varietal clones had decreased in 5 of the 10 industries. The largest decline appeared in farmers' cooperatives. Winery A has shown a decline of $35 \%$ in processing, contrasting the period of 90-93 with 94-99. This company does not adopt incentive mechanisms of price and quality and had shown signs of moving to low quality, commodity wine, sourcing 
the product from other wineries. On the other hand, the wineries that increased its production were vertically integrated and those that adopt incentives to maintain stable relationships with farmers.

Provided that the qualitative analysis indicated the importance of specific investments associated to incentive standards or other mechanisms for vertical integration, the next part of the paper will search for quantitative evidences on the stability of contractual relationships between farmers and wineries.

The qualitative analysis offered some insights inviting to a deeper analysis of the contractual characteristics adopted to coordinate the production. We have chosen a transaction cost perspective approach, where the re-contracting rate between particular farmers and winery is the dependent variable. Since we had alternative measures of asset specificity, we have enriched the qualitative analysis exploring a particular angle of the contractual structure of production, relating the stability measure with transaction cost explanatory variables. This approach is unexplored in the literature but is aligned with Joskow (ditto) approach on contract length in the US coal industry and Zylbersztajn and Lazzarini (ditto) approach on contract length on Brazilian seed industry.

\section{Empirical Analysis}

We estimated an Ordinary Least Square (OLS) model to relate a proxy for stability of the transaction between the vineyard and the processing winery. The idea is to capture the average frequency of contracts among the same agents considering the period of five years $(t)$, the 10 wineries (j), and a sample of 139 farmers (i), taking into account that the vineyards are free to renegotiate the annual contracts at the end of each period. In this way, we captured the effects of explanatory variables on the farmers' decision to re-contract with different wineries. By creating an index of re-contracting, we have reduced the panel structure of the data to a simpler one, reducing the time dimension and exploring the farmer-winery relation. ${ }^{3}$

\footnotetext{
${ }^{3}$ In order to run a panel data analysis we would have to collect farmers' level data, which was not possible due to cost considerations.
} 


\subsection{Description of variables}

We defined msv as the average of vintages made between a farmer and a winery within the sample of 10 processing industries. The dependent variable captures the average number of transactions, sequential or not, ranging from 5 , if the farmer re-contracts with the same industry during the five years, to 1 , if the farmer contracted a different industry each year. We named this dependent variable the mean vintages per vineyard. The dependent variable is based on the observation of transactions between farmer $i$ and winery $j$, in year $t$. For each farmer the average of vintages per winery was calculated.

Explanatory variables are different measures of asset specificity, namely:

Age of vineyard: The age is directly related to the product quality. The local research station specializing in grape and wine production suggests that the first economic vintage should be made on the fourth year, but the quality improves after the 6th year. The production period lasts until the 15th year and the highest quality of the product is reached between year 6 and 15. In order to capture this condition, a quadratic function was defined at the equation 1 :

$$
\mathrm{Kt}=\mathrm{a}+\mathrm{b} . \mathrm{ivt}+\mathrm{c} . \mathrm{ivt} 2 \text { (1), }
$$

where ivt is the vineyard's age.

Distance (dmv): This variable captures the existence of site specificity and measures its effect on contract frequency. Distance between each specific vineyard and the industry has been calculated. Standard distance logistics software could not be used for this purpose, since our intent is to measure the distance between the specific farm and the vineyard, and the software offer only distances between cities. The dmv variable was defined based on the distances table.

Size (scale): This variable captures the effect of winery scale on the stability of the transaction. Scale here is measured by the annual production of the winery.

Cooperative (dc): Due to the importance of farmers' cooperatives in Brazilian agro-food industry and specifically the results of the qualitative 
analysis, which indicated the declining importance of cooperatives in the wine industry, a dummy variable has been defined in order to capture the particular group. Since farmers tend to transact with more than one industry, the dummy is considered to be equal to one, if the largest vintage in the five-year period was made with a cooperative.

\subsection{Transaction Cost Hypothesis}

A multiple regression model has been defined as follows:

MSV $=\mathrm{a}+\mathrm{b}$ ivt $+\mathrm{c}$ ivt $2+\mathrm{d} d m v+\mathrm{e} d \mathrm{c}+\mathrm{f}$ scale $+\mathrm{u}(2)$, where $\mathbf{u}$ denotes the error term with the well-behaved characteristics assumed.

The variable ivt captures the asset specific investment related to the vineyard age, and it is expected that the range between 6 and 15 years should relate positively to the dependent variable and negatively otherwise. We expect that wineries prefer to re-contract with vineyards that are more likely to offer good quality grapes. Too young or too old vineyards are not expected to offer the desirable quality to produce fine wines. It follows that $\mathrm{b}$ is expected to be positive and $\mathrm{c}$ should be negative.

The distance variable, dmv captures site specificity. It is expected to be negatively related to stability, since the larger the distance, the larger the risk exposure during the transportation of the grapes from the fields to the industry. Therefore, this variable captures the effect of perishability, very common in some food industries, supporting the hypothesis of a negative effect of this variable, i.e. the smaller the distance the larger the measure of stability. The processing industry is interested to re-contract with nearby farmers.

The dummy variable captures the cooperative membership effect. On the one hand, since farmers are owners of the cooperative, a more stable relationship is expected in this type of organization in contrast with noncooperatives. On the other hand, the qualitative analysis suggests that the number of cooperatives is declining in importance, specifically the ones engaged in the production of fine wines. The relative importance of farmers' cooperatives is declining, especially in the production of differentiated products. 
Possibly the best farmers have already left the cooperative system, preferring the investor-owned industries, which offer extra incentives in the presence of quality attributes. So, adverse selection applies. Another argument to support a positive relationship between farmers and the cooperative is the ideological commitment. So, based on their beliefs, members prefer to trade with the cooperative, resulting in an expected positive sign for parameter $\mathbf{e}$.

We expect that scale of production be negatively related to quality. This is associated to the difficulty in coordinating a large number of suppliers and controlling quality attributes. Smaller wineries, mostly vertically integrated backwards, are expected to show better capacity to coordinate the production to reach specific quality attributes.

\subsection{Empirical Results and Analysis}

We estimated an OLS model using a robust matrix to correct the heteroscedasticity problem, tested by White's test (Chi-sq (18) P-value $=0.0343$ ) in OLS usual estimative. Note, however, that the White's statistic test is in the edge of interval, i.e. the model is not considered homocedastic only at $1 \%$ of significance. This explains why the robust estimation did not differ much from the OLS estimate.

Basic statistic results are presented in table 4. The two parameters related to age specificity did not present a statistically significant result at the level of $5 \%$, although their signs are according the expected ones ${ }^{4}$. The variable ivt associated has been kept in the model, because the usual tests for specification of nested models, such as F and adjusted-R2, indicated a better specification with them in. Besides, these variables - ivt and ivt2- are strongly correlated, as shown in table 3 , causing positive bias in estimated variances and, consequently affecting the significance of $t$. So, considering this aspects, we cannot conclude that the vineyard age in not important to explain the re-contracting, being kept as explanatory variable.

\footnotetext{
${ }^{4}$ The age term is positive; indicating that old vineyards are re-contracted more than the newer. The quadratic term is negative can be interpreted as the wineries tending to prefer to contract with farmers that have "good" vineyards, not too old, not too young.
} 
Table 3 - Matrix of Dependent Variables Correlations

\begin{tabular}{llllll}
\hline Correlations & Ivt & ivt2 & dmv & Dc & scale \\
\hline Ivt & 1 & & & & \\
ivt2 & 0.9578 & 1 & & & \\
dmv & 0.0628 & 0.0535 & 1 & & \\
dc & 0.0282 & 0.0354 & -0.2753 & 1 & \\
scale & 0.0026 & 0.0039 & -0.0922 & 0.4468 & 1 \\
\hline
\end{tabular}

Table 3 also indicates multicollinearity with variables dc and scale since cooperatives in general are large. We kept them in the model because the correlation is not prohibitively high and also because removing one of them introduces bias due to the omission of a relevant variable.

Table 4 - Estimated model of stability of transactions

\begin{tabular}{|c|c|c|c|c|c|c|c|}
\hline \multicolumn{8}{|c|}{ Robust Estimation } \\
\hline \multicolumn{6}{|c|}{ Dependent variable: msv } & \multicolumn{2}{|c|}{ n.139 obs. } \\
\hline & coef. & Coef. & Std. Err. & $\mathrm{t}$ & $P>|t|$ & {$[95 \% \mathrm{Cor}$} & [nt.] \\
\hline Cte & A & 2.2514 & 0.4249 & 5.30 & 0.000 & 1.4109 & 3.0919 \\
\hline Ivt & $\mathrm{B}$ & 0.0830 & 0.07115 & 1.17 & 0.246 & -0.0577 & 0.2237 \\
\hline ivt2 & $\mathrm{C}$ & -0.0042 & 0.0027 & -1.55 & 0.123 & -0.0094 & 0.0011 \\
\hline $\mathrm{Dmv}$ & $\mathrm{D}$ & -0.0667 & 0.0167 & -3.98 & 0.000 & -0.0998 & -0.0336 \\
\hline Dc & $\mathrm{E}$ & 0.5270 & $4.21 \mathrm{e}-08$ & 2.10 & 0.038 & 0.030 & 1.0236 \\
\hline Scale & $\mathrm{F}$ & $1.65 \mathrm{e}-07$ & 0.4249 & 3.91 & 0.000 & $8.14 \mathrm{e}-08$ & $2.48 \mathrm{e}-07$ \\
\hline$F(5,133)$ & $=15.93$ & Prob $>F=$ & 0.0000 & R-squa & $\mathrm{d}=0.36$ & Root MSE & 1.2048 \\
\hline
\end{tabular}

The parameter related to site specificity has shown a significant negative relationship with the dependent variable. The interpretation is that the shorter the distance, the larger the expected stability of the contracts between farmers and wineries, which is a robust result expected from the theory, therefore confirming our hypothesis.

The dummy for cooperatives has shown a positive and significant parameter, leading to the conclusion that cooperative members show more stable relationships with the cooperative. This implies that the macro-hierarchy (Lazzarini, et al., 2000.) represented by the cooperative does show unexplored superior capacity to coordinate both horizontally, among farmers facilitating the introduction of new varieties and the adoption of technology in general, and verti- 
cally, facilitating the coordination between farm and industry, and also with farm suppliers, usually intermediated by the cooperatives. Other reasons, related to the negative incentives provided by this organization arrangement, however, preclude the exploration of the coordination capacity.

Scale has shown a positive significant parameter, not confirming the working hypothesis. This can be explained, on the one hand, by the correlation between the size and the cooperatives, therefore interfering in the parameter estimates. On the other hand, the smaller firms might show superior capacity to coordinate the production. Deeper analysis should be carried.

\section{Conclusions}

Quality attributes are essential to the food industry in general and their control introduces important elements for vertical coordination. This study has shown that the concept of stability of sequential contracts measured by the frequency of transactions between the same agents, when choice is possible, can be explained by traditional measures of transaction cost analysis. Basically farmers and processing industries do consider organizational elements when drafting contracts. Asset specificity is shown to be relevant, reinforcing the results found in the literature of economics of organizations in the last decade.

The present study reveals that built-in contractual incentives are important for strategic design. Being so, this opens room for a research approach in which qualitative analysis can be carried together with quantitative studies of institutional design of coordination mechanisms in food chains.

Since the evolution of food industries show social impacts in developing countries, the case of Rio Grande do Sul indicates that institutional aspects must be considered. First, market-augmenting institutions might be introduced or improved, with the law of denomination of origin and agencies for monitoring quality, for example. The qualitative analysis has shown that farmers' cooperatives do not adopt the same standards of incentives as observed by non-cooperatives. Also, other incentives related to horizon and political problems, 
as explored in the literature on the new generation of cooperatives (Cook, ditto), are possibly related to the findings of this study. The result leads to further discussion on the tradeoffs shown by farmers' cooperatives, mixing the advantages provided by the personal informal interaction with cultural ties relating the agents. However, the benefits of the named aspects are crowded out by the costs associated to the disincentives in terms of property rights on the residuals, causing each individual farmer to prefer to leave the cooperative and choose to contract with for-profit companies.

Finally, since long-lasting relationships evolve in stable contracts, especially in food chains, an opportunity for further studies rests in the exploration of the concept of dynamic capabilities, developed among independent but contract-related agents throughout the food chain.

\section{References}

AKERLOF,G.(1970). The Market for Lemons: Quality Uncertainty and the Market Mechanism. Quarterly Journal of Economics 84:488-500.

BARKEMA, A. D. (1993). New Roles and Alliances in the US Food System. Paper presented at the Spring Meeting of the Federal Reserve System Committee on Agriculture and Rural Development. Kansas City.

BROUSSEAU, E. e CODRON, J. M. (1997). The Hybridization of Governance Structures: Supplying Supermarkets with Off-Season Fruit. Prepared for the SFER Congress Modern Food Retailing, May 22-23, Montpellier-France.

CHADDAD, F. R. (1996). Denominações de Origem Controlada: uma alternativa de adição de valor no agribusiness. São Paulo. Dissertação de Mestrado - FEA/USP.

COOK.M.(1994). The Evolution of US Agriculture Cooperative Financial Strategies. International Agribusiness Seminar. PENSA-University of São Paulo.

DAVIS, J. H. e GOLDBERG, R. A. (1957). A Concept of Agribusiness. Harvard University Press, Boston. 
FRANK. S. D. e HENDERSON, D. R. (1992) Transaction Cost as Determinant of Vertical Coordination in the U.S. Food Industries. American Journal of Agricultural Economics, November.

GEENE, A., HEIJBROEK, A., LAGERWEST, A., WATIR, R. (1999). The world wine business. Market study. Food and Agribusiness Research. Rabobank International.

GIRAUD-HÉRAUD, E., SOLER, L. G. e TANGUY, H. (1998). "Regulation de l'Offre et Interprofessions Viti-Vinicoles: Questions Theoriques et Problèmes Empiriques". OIV, XXIII Congrés Mondial. Lisbone, Portugal.

GOLDBERG, R.A. e DANIELS D. (1998). Marchesi De'Frescobaldi: Integrating Traditions and Change in One of Italy's Oldest Industries. Case for class discussion. Harvard Business School, N9-599-074. Boston.

JALFIM, A. (1991). Elementos para o estudo da agroindústria vinícola: uma abordagem da Indústria Vinícola Rio-Grandense. Ensaios FEE, Porto Alegre, 12(1): 229-247.

JOSKOW, P. L. (1985). Vertical integration and long term contracts. The case of coal burning eletric generation plants". Journal of Law Economics and Organizations, p. 33-79.

KLEIN, B., CRAWFORD, G., ALCHIAN A. (1978). Vertical integration Appropriable rents and the competitive contracting process. Journal of Law and Economics, n.21, p. 297 - 326.

LANGLOIS (1992). Transactions cost economics in real time. Industrial and Corporate Change, v.1, n.1, p. 99-124.

LAPOLLI, J. N. et all. (1995). A competitividade da vitivinicultura brasileira: análise setorial e programa de ação com destaque para o Rio Grande do Sul. Porto Alegre, RS: BANRISUL / EMBRAPA- CNPUV/ SEBRAE/RS. 200 p.

LAZZARINI (2001). Integrating supply chain and network analyses: The study of netchains. Jornal on Chain and Network Science. Vol 1, n. 1, p. 7-22.

LAWRENCE, J. D. et al., (1997). Vertical Coordination in the US Pork 
Industry: Status, Motivations and Expectations. Agribusiness, Vol. 13, $\mathrm{n}^{\mathrm{o}} 1$, p. 21-31.

MARIOTTI, S. e CAINARCA, G. C. (1986). The Evolution of Transaction Governance in the textile-Clothing Industry. Journal of Economic Behavior and Organization, pp.351-374 (I).

MATTUELLA, J. L. and ROHR, E. J. (1993). A produção de uva no contexto do Mercosul in Congresso Brasileiro de Economia e Sociologia Rural. Ilhéus, BA, Anais.

MENARD, C. (1996). On clusters, hybrids and other strange forms: the case of the French poultry Journal of Institutional and Theoretical Economics. 152 (1). 154 - 183.

MIELE M. (2001). Análise da transação entre produtores de uva e agroindústria vinícola: o caso dos vinhos finos no sistema agroindustrial vitivinícola do Rio Grande do Sul. São Paulo. Dissertação de Mestrado - FEA/USP.

RABOBANK (1996). The world wine business. Developments and strategies. Netherlands.

SAUVEÉ (1998) Towards an Institutional Analysis of Vertical Coordination in Agribusiness". In The Industrialization of Agriculture. Royer,J. S. and Rogers,R.T. eds.

SOLER, L.G. e TANGUY, H. (1998). Contrats et Négotiations dans le Secteur des Vins de Champagne. In Annales de Mines, mar.

SOUZA, N. J. de (1994). O complexo agroindustrial e a produção brasileira de vinhos, milho, aves e soja no contexto do Mercosul. Texto para discussão n 94/06, Curso de Pós-Graduação em Economia, UFRGS. Porto Alegre.

WILLIAMSON, O. (1985). The Economic institutions of Capitalism: Firms, Markets, Relational Contracting. The Free Press, New York, pp. 450.

ZYLBERSZTAJN, D. and FARINA, E. M. M. Q. (1999). Strictly Coordinated Food Systems: Exploring the Limits of the Coasian Firm. International Food and Agribusiness Management Review. Vol 2, n.2. 
ZYLBERSZTAJN,D and LAZZARINI,S.G. (2005). On the survival of contracts: Assessing the stability of technology licensing agreements in the Brazilian seed industry. Journal of Economics and Business Organization, vol. 56:103-120. Table 1: Governance structure of wineries in Rio Grande do Sul (Sample, year 2000).

Recebido em fevereiro de 2004 e revisto em abril de 2005. 